\title{
ТЕХНОЛОГІЯ ВИГОТОВЛЕННЯ ПОЛЕГШЕНИХ СКЛАДІВ ЦЕМЕНТНИХ СУХИХ БУДІВЕЛЬНИХ СУМІШЕЙ З МІНЕРАЛЬНИМИ ДОБАВКАМИ
}

\author{
Бондар А. В., асистент \\ Украйна, м. Вінниия, Вінницький національний технічний університет, кафедра будівництва, \\ міського господарства та архітектури
}

DOI: https://doi.org/10.31435/rsglobal_wos/28022019/6339

\section{ARTICLE INFO}

Received: 22 December 2018

Accepted: 23 February 2019

Published: 28 February 2019

\section{KEYWORDS}

dry building mortar, mortar mixture, average density, strength, production technology, technological scheme, mixing, grinding, joint grinding, floor mix, mineral additives, porous additives, porous structure, polymer additives.

\begin{abstract}
The article deals with the technological features of manufacturing of lightweight cements of dry building mixtures with mineral additives. The technology of obtaining mortars from dry mixtures should take into account the fact that the processes of hydration of cement binder occur with insufficient water. Therefore, the possibility of obtaining lightweight dry mixtures based on Portland cement and mineral additives with the use of foaming additives is investigated. The use of a complex of technological operations allows you to obtain mixtures for the installation of warm floors, which are characterized by stable technological and physical and mechanical properties, as well as the simplicity and economy of manufacturing technology. Effective mixtures of porous structure have been obtained from for the warm floors on the basis of conventional dense (heavy) fillers and fillers, such as quartz sand, clay, carbonate sand, ash-removal of thermal power plants. The technological scheme of factory production of dry mixtures has been obtained while saving the binder component.
\end{abstract}

Citation: Бондар А. В. (2019) Technology of Fabrication of Lightweight Cementitious Dry Building Mixtures with Mineral Additives. International Academy Journal Web of Scholar. 2(32). doi: 10.31435/rsglobal_wos/28022019/6339

Copyright: (C) 2019 Бондар А. В. This is an open-access article distributed under the terms of the Creative Commons Attribution License (CC BY). The use, distribution or reproduction in other forums is permitted, provided the original author(s) or licensor are credited and that the original publication in this journal is cited, in accordance with accepted academic practice. No use, distribution or reproduction is permitted which does not comply with these terms.

Вступ. Виготовлення сухих будівельних сумішей (СБС) на основі портландцементу та мінеральних добавок $є$ досить актуальним в умовах сировинних запасів Українського регіону, повторного використання відходів промислового та енергетичного комплексу, а також високих вимог сучасного споживача до якості будівельних розчинів та технологій виконання будівельних робіт [1-4]. Розробка складів мінеральних сухих будівельних сумішей 3 пониженою середньою густиною, тобто полегшених, $є$ актуальним для забезпечення вищих показників щодо тепло- та звукоізоляції приміщень цивільних будівель, а також можливості полегшення ваги конструкцій, наприклад, міжповерхового перекриття, підлог тощо без втрати міцності та перевитрат в'яжучого і функціональних хімічних добавок [4-6].

Проблематика отримання полегшених СБС. Технологія отримання легких СБС та розчинів на їх основі сьогодні переважно відбувається шляхом розробки складів на основі 
легких природніх (перліт, вермикуліт), штучних (керамзит, пористі шлаки та золи промисловості, відходи виробництва піно- та газобетонів), органічних (легкі пінополістирольні кульки) заповнювачів та окремо складів для виготовлення пінобетонних сумішей чи розчинів для пінобетонної кладки. Виробництво власного сухого піно- чи пороутворювача для СБС тягне додаткові затрати на підбір хімічних компонентів та дослідження властивостей самої добавки та іï поводження у складі сухої, а згодом розчинової суміші [7]. Широке поширення мінеральної сировини у надрах України, великий запас відходів промисловості (паливних зол та відходів обробки гірських порід) та розвинуте цементне виробництво робить актуальним питання виготовлення полегшених СБС на основі портландцементу та мінеральних добавок [1, 8-10]. Для ефективного зниження середньої щільності та утворення пористої структури затверділого розчину, виготовленого на основі таких СБС, ефективно вводити у їх склад поверхнево-активні речовини та піноутворюючі добавки $[11,12]$. Проте такий метод має кілька суттєвих недоліків, що пов'язано 3 природою тверднення і структуроутворення цементного каменю в сухих будівельних сумішах, складністю забезпечення стабільності високопористої структури розчину, поверхневих міжфразових явищ у поризованих (особливо піноутворючими добавками) сумішах, мінералогічним і гранулометричним складом СБС, що являються багатокомпонентними системами, а також впливом технологічних особливостей виробництва СБС та технології приготування розчинової суміші із розроблених СБС в умовах будівельного майданчику $[11,13,14]$.

Процеси структуроутворення в полегшених цементних сухих будівельних сумішах 3 мінеральними добавками. У структуроутворенні i формуванні фізико-механічних властивостей цементного каменю дуже важлива роль належить процесу утворення пор (гелевих, контракційних, капілярних) [15]. Головне значення у виникненні системи пор має відносний вміст у цементному тісті води. Загальна пористість цементного каменю залежить від значення величини водоцементного відношення, яке може змінюватися в межах $-0,35 \ldots 0,7$. Відповідно загальна пористість змінюється від 25 до 50\%. Незважаючи на досить високу загальну пористість цементного каменю він має дуже високу водонепроникність порівняно навіть із щільними гірськими породами.

Тверднення і структуроутворення цементного каменю $є$ основними процесами, які формують найважливіші властивості - міцність, деформативність, проникність, довговічність тощо [16]. Наявність у структурі розчину заповнювачів певним чином впливає, як на кінетику структуроутворення, так i на результат цього процесу. Частина води замішування «відтягується» заповнювачем для змочення поверхні його зерен і ця частина тим більша, чим більша питома поверхня зерен. В цих умовах знижується В/Ц, що впливає на кінетику структуроутворення цементного каменю. Заповнювач підвищує водоутримувальну здатність цементного тіста, безпосередньо впливає на реологічні властивості розчинової суміші. Ступінь цього впливу залежить від концентрації заповнювачів у суміші. Структуруюча роль заповнювача проявляється в обмеженні, зв'язуванні об'ємних деформацій тверднучого цементного тіста і каменю [17].

Технічні властивості цементних розчинів залежать від складу і структури цементного каменю. Мікроструктура цементного каменю має значний вплив на його міцність. Цементний камінь, який має блоково-шарову структуру, відносно легко розширюється при згині, розривається при розтягу і має повзучість під впливом постійно діючого навантаження [17].

Активація цементу після певного часу його взаємодії з водою, яка $є$ неоднаковою для різних видів цементу, може призвести до падіння міцності і навіть руйнування цементного каменю. Тому структуру розчинів модифікують добавами органічних поверхнево-активних речовин (ПАР) [17]. При цьому знижується водопоглинання і капілярне всмоктування, зростають морозостійкість і водонепроникність.

Однак, для процеси стуктуроутворення у сухих будівельних сумішах відбуваються при недостатній кількості води, що пояснюється строгим обмеженням вологості компонентів суміші на стадії виробництва і фасування у тару, а також вбиранням частини вологи із суміші на стадії іï нанесення на поверхню та випаровуванням з поверхні при великих площах виробів при твердненні в реальних умовах невисокої відносної вологості повітря. Це призводить до перевитрат в'яжучого та зниження міцності затверділого розчину, що вимагає використання добавок, що зберігають пластичність цементного розчину без збільшення В/Ц-відношення [18]. 
У технології виготовлення поризованих СБС та розчинів на їх основі не можна застосовувати звичні методи ущільнення розчинової суміші для отримання однорідності розчину та підвищення його міцності. Метод короткочасного віброущільнення допустимий лише для рівномірного розподілу суміші по поверхні чи у формі виробу, так як під дією вібрації відбувається розрідження суміші, ऑiі щільне укладання і видалення повітря, яке міститься в ній. Застосування пластифікаторів знижує загальну кількість води в системі, якої і так недостатньо для протікання процесів гідратації цементу, а ії збільшення може призвести до негативних усадочних явищ. Більш ефективним способом підвищення щільності розчинів, отриманих на основі СБС, $€$ введення в їх склад полімерів у вигляді редиспергуючих полімерних порошків. Крім ущільнення цементного розчину полімери, адсорбуючись на ростучих гранях кристалів гідратних нооутворень, створюють специфічну захистну оболонку i таким чином стабілізують гідратні фази [19]. В багатьох сухих будівельних сумішах для збереження води в структурі тверднучого матеріалу використовуються спеціальні водоутримуючі добавки - ефіри целюлози, які сповільнюють процес гідратації цементу.

Поверхнево-активні речовини (ПАР) у технології полегшених мінеральних СБС дозволяють знизити водопотребу суміші, завдяки адсорбційній взаємодії з твердою фазою при змішуванні з водою, виникненню ефекту електростатичного відштовхування [20], втягненню у суміш дуже дрібних бульбашок повітря та їх стабілізації в цементному тісті, адсорбції на поверхні розділення фаз «повітря-вода», зниженню поверхневого натягу води та іiі рівномірному розподілу на поверхні цементних частинок і мінеральних складових суміші. Також ПАР полегшують змочування водою твердих компонентів розчинової суміші. Такими чином відбувається утворення однорідної структури розчину 3 рівномірно розподіленими замкнутими порами та підвищення іï стійкості, покращення реологічних властивостей розчинової суміші, а отже, і якості затверділого розчину при економії цементу. Проте ПАР не дозволяють значно знизити середню щільність СБС з мінеральними добавками. 3 цією метою виникає необхідність застосування піноутворюючих добавок, які викликають утворення в цементному камені замкнутих сферичних макропор 3 розмірами від 0,1 мм до кількох міліметрів. Високопориста структура вимагає додаткової стабілізації, що можливо при додатковій активації компонентів суміші для підвищення міцності матриці поризованого матеріалу. Забезпечення міцності неорганічної матриці можливо шляхом підвищення хімічної активності в'яжучого, зниження В/Ц, використання механо-хімічної активації в'яжучого та механічної активації мінеральних компонентів суміші, підбором гранулометрії, виду та кількісного вмісту мінеральних добавок. Створення оптимальної пористої структури залежить від кратності і стійкості піни в високомінералізованих цементних пастах, а розмір i дисперсність повітряних бульбашок залежать не тільки від виду обраних вихідних компонентів, але і від поведінки компонентів на межі розділу фаз, тобто від поверхневих явищ, i від способу повітровтягнення. Важливу роль при цьому відіграє вид (синтетичного або природного походження, як правило, аніоноактівного типу) та концентрація піноутворювача, що має в своєму складі ПАР, а також технологія приготування розчинової суміші [21-24]. Варто враховувати спільну роботу ПАР і мінеральних часток, що входять до складу піноцементної поризованої суміші. Так, вплив твердої фази на стійкість найбільш сильно виявляється в тому випадку, якщо знак заряду твердої фази протилежний знаку заряду іона ПАР [25]. Кратність піни підвищується, якщо в піну вводиться мінеральний порошок, який має однаковий знак заряду поверхні із зарядом поверхні повітряної бульбашки. Таким чином між пінними бульбашками і мінеральними частинками відзначається електростатична взаємодія, яка визначається величиною заряду поверхні мінеральних часток і активністю гідрофільного радикала ПАР і впливає на кратність і стійкість піни [7, 9, 11, 13].

Результати досліджень. В результаті виконаних теоретико-експериментальних досліджень отримано склад мінеральних цементних СБС на основі відходів промисловості 3 оптимальними фізико-механічними та спеціальними властивостями поризованих розчинів, отриманих на основі цих сумішей [1-3]. Розроблені оптимальні склади СБС із мінімальним вмістом цементу ПЦ 500, - в межах 10-25\% від маси суміші з використанням карбонатного заповнювача, який отримується 3 відходів різання карбонатних порід, мінерального мікронаповнювача у вигляді глиняного порошку, кварцового піску та золи-винос [1-4, 6]. Отримані склади СБС, що дають розчини М30-М200 (M200 - при збільшенні витрат ПЦ до 
$55 \%$ ): ПЦ - 10\%, ВП (крупністю 0,315; 0,63; 1,25 мм) - 30\%, ГП (крупністю 0,315; 0,63) - 60\%; ПЦ - 10\%, ГП (крупністю 0,315) - 70\%, ЗВ - 20\%; ПЦ - 10\%, ГП (крупністю 0,315) - 15\%, П $60 \%$, ЗВ - 15\%; ПЦ - 10\%, ВП крупністю 0,315) - 22,5\%, ГП (крупністю 0,315) - 22,5\%, ЗВ $22,5 \%$; ПЦ - 10\%, П - 70\%, ЗВ - 20\%; ПЦ - 10\%, ВП (крупністю 0,315) - 70\%, 3В - 20\%; ПЦ $10 \%$ (крупністю 0,63), ГП (крупністю 0,63 ) - 22,5\%, П - 22,5\%, 3В - 22,5\%. Досліджено фізикомеханічні властивості поризованої будівельної суміші, приготованої на основі оптимальних складів СБС, вплив на них різного кількісного та гранулометричного складу компонентів, виду піноутворювача і його концентрації, полімерних добавок. Отримані поризовані склади СБС марки 15 і вище (при збільшенні кількості ПЦ).

Досліджено вплив мінеральних добавок у складі СБС на підвищення технічних характеристик пін та піннодисперсних систем розчинів СБС. Встановлено, що введення до складу полегшених СБС та, отриманих на їх основі, поризованих розчинів тонкодисперсного глиняного порошку (крупністю до 0,315 мм) у кількості 15-18\% (від маси сухої суміші) дозволяє стабілізувати піно-цементу систему, підвищити ступінь гідратації в'яжучих в СБС за рахунок залишкової води, яка вивільняється внаслідок диспергуючої здатності глинистих мінералів, пластифікуючих та адсорбційних властивостей глин [2, 7-9].

Встановлені залежності основних характеристик розроблених СБС та отриманих на їх основі поризованих розчинів від кількісного складу основних компонентів суміші, виду і гранулометрії наповнювачів. Отримані математичні залежності впливу концентрації сухого аніонного піноутворювача, виду, кількості і гранулометрії мінеральних наповнювачів, витрат портландцементу та відношень водотвердного (В/Т) i Ц/3 (Н - наповнювач) на значення середньої щільності та міцності отриманих полегшених СБС $[2,10,14]$. Їх використання дозволяє прогнозувати і забезпечувати необхідні значення водопотреби, повітровтягування, рухливості, міцності, середньої щільності та акустичних властивостей залежно від вимог до СБС за призначенням $[3,4,6]$.

Встановлено, що карбонатний мікронаповнювач здатний впливати на процеси структуроутворення цементних композицій в складі поризованих сухих будівельних сумішей. Це пояснюється створенням цим наповнювачем додаткових поверхонь розділу фаз, що сприяє більш рівномірному розподілу пор в структурі під час перемішування суміші з водою, а також не руйнування пор під час протікання фізико-хімічних процесів тверднення в'яжучого. Карбонатний мікронаповнювач наповнює в'яжуче, збільшуючи його питому поверхню, а поверхнева енергією частинок, яка виникає, як наслідок високої дисперсності карбонатних пісків і порошків, підвищує міцність складів СБС $з$ пористою структурою Карбонатний наповнювач, маючи хімічно активність, сприяє рівномірному розподілу ПАР в розчинної суміші, а також дозволяє використовувати глинисті порошки, як стабілізатори ПАР та піноутворюючих добавок $[2,3,5]$.

Спільне механічне подрібнення карбонатного заповнювача разом із золю-винос, цементом та іншими добавками дозволяє отримати сухі будівельні суміші пористої структури 3 міцністю від 3,84 до 14,02 МПа, які відрізняються зниженням В/Т співвідношення без втрати рухливості розчинної суміші, покращеними тепло-звукоізоляційними властивостями $[3,14]$.

Технологія виготовлення полегшених складів цементних сухих будівельних сумішей $з$ мінеральними добавками складається з наступних етапів (див. рис. 1):

1) подрібнення вапнякових відходів в молотковій дробильні з решіткою до фракції 0-10 мм;

2) сушка вапнякових відходів до вологості $<0,5 \%$;

3) подрібнення вапнякових відходів в бігунах до розміру зерен 5 мм і менше;

4) висушування глини до сталої маси;

5) подрібнення глини у бігунах до розміру зерен 0,315 мм, 0,65 мм і 1,25 мм;

6) просіювання вапняного порошку через сита №5, №2, 5 , №0,63, №0,315;

7) просіювання глиняного порошку через сита №1,25, №0,63, №0,315;

8) висушування кварцового піску до сталої маси;

9) просіювання кварцового піску через сито №1,25;

10) дозування компонентів;

11) спільне змішування кварцового піску та $1 / 4$ частини портландцементу протягом 5-10 хв.;

12) дозування та спільний помел у бігунах спочатку вапнякових відходів з золою-винос, а потім і з 1/4 частиною портландцементу протягом 5-10 хв.; 
13) розсів порошку через сито №1,25 3 поверненням не просіяного залишку на подрібнення у бігуни;

14) спільне змішування отриманих сумішей протягом 5-10 хв. до домелу суміші до необхідної однорідності та гранулометрії;

15) дозування глиняного порошку, редиспергованого порошку, ефіру целюлози та перемішування протягом 5 хв. із 1/4 частиною портландцементу;

16) дозування ПАР та/ або піно-, пороутворюючих добавок та спільне перемішування протягом 5 хв. із 1/4 частиною портландцементу;

17) дозування мінеральних заповнювачів з розміром зерен 0,315 мм, 0,65 мм та спільне перемішування протягом 10-15 хв. із отриманою сумішшю портландцементу та добавок;

18) додавання при необхідності полімерних волокон довжиною до 6 мм та спільне перемішування протягом 5-10 хв. із отриманою сумішшю портландцементу, мінеральних заповнювачів та добавок;

19) розфасовка суміші;

20) пакування та відвантаження готової продукції на склад.

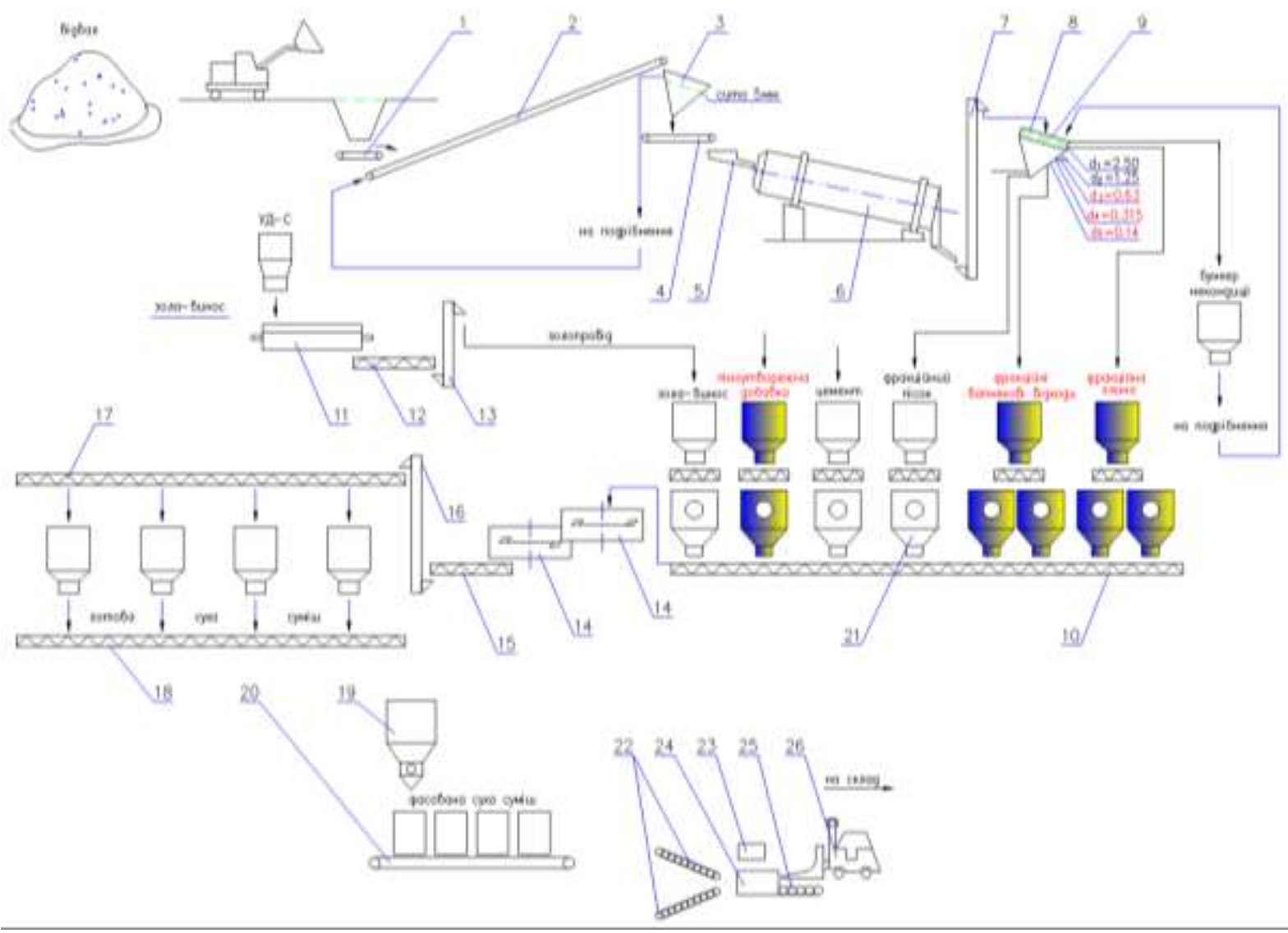

Рис. 1. Технологія отримання поризованих мінеральних СБС на заводі:

1 - стрічковий живильник; 2, 4, 20 -стрічковий транспортер; 3 - грохот контрольний; 5 загрузочна воронка; 6 - сушильний барабан; 7 - елеватор; 8-грохот; 9 - сортувальне сито; 10, 12, 15, 17 - шнек; 11 -стержневий змішувач; 13, 16 -ковшовий елеватор; 14 -лопатевий змішувач; 18 - гвинтовий жсивильник; 19 - силос для роздачі у мішки; 21 - дозатор; 22 - каток для мішків; 23 - итамп-машина; 24 - термоусадочна камера; 25 - рольганг зйому піддонів;

$$
25 \text { - вилочний автонавантажувач }
$$

Висновки. Розроблено енерго- та ресурсозберігаючу технологію отримання поризованих мінеральних СБС 3 покращеними тепло-звукоізоляційними характеристиками (див. рис. 1) [3, 5-10, 12-14], де враховані додаткові операції сушіння, подрібнення, механічної активації мінеральних та дозування компонентів суміші. 


\section{ЛІТЕРАТУРА}

1. Очеретний В. П. Перспектива виробництва і використання поризованих сухих будівельних сумішей / В. П. Очеретний, А. В. Бондар // Науково-технічний збірник «Сучасні технології, матеріали і конструкції в будівництві». - Вінниця: ВНТУ, 2011. - № 2. - С. 36-39.

2. Бондар А. В. Вплив мінеральних мікронаповнювачів на властивості поризованих сухих будівельних сумішей / В. П. Очеретний, В. П. Ковальський, А. В. Бондар // Вісник Сумського національного аграрного університету. Серія: «Будівництво», 2014. - Випуск 10 (18). - С. 44-47.

3. Бондар А. В. Утилізація відходів промисловості шляхом виготовлення на їх основі сухих будівельних сумішей / А. В. Бондар, В.П. Ковальський, В.П.Бурлаков, С. Р. Матвійчук // Екологічні науки: науково-практичний журнал. - К: ДЕА, 2018. - № 3(22). - С. 21-24. - ISSN 2306-9716.

4. Бондар А. В. Теплозвукоізоляційні властивості поризованих сухих будівельних сумішей для підлог / А. В. Бондар, В. П. Очеретний // Тези XLV Науково-технічної конференції факультету будівництва, теплоенергетики та газопостачання (2018), ВНТУ [Електронний ресурс] // Електронне наукове видання матеріалів конференції. - Вінниця: ВНТУ, 2016. - Режим доступу до ресурсу: https://conferences.vntu.edu.ua/index.php/all-fbtegp/all-fbtegp2016/paper/view/1410/1005.

5. Бондарь А. В. Использование карбонатных пород как микронаполнителей в сухих строительных смесях пористой структуры / В. П. Ковальський, В. П. Очеретный, А.В.Бондарь // Актуальные проблемы архитектуры, строительства, энергоэффективности и экологии - 2016: сборник материалов международной научно-практической конференции. - В 3-х т. - Т. І. - Тюмень: РИО ФГБОУ ВО Тюменский индустриальный университет, 2016. - С. 207-213.

6. Ковальский В. П. Звукоизоляционные сухие строительные смеси на основании отходов производства / В. П. Ковальский, В. П. Очеретный, А. В. Бондарь // Инновационное развитие территорий: Материалы IV Междунар. науч.-практ. конф. (г. Череповец, 26 февраля 2016 г.). Череповец: ЧГУ, 2016. - С. 73-78. - ISBN 978-5-85341-688-8.

7. Очеретный В. П. Поризованные сухие строительные смеси: эффективность получения сухого пенообразователя методом сорбции и выпаривания / $\quad$ В. П. Очеретный, $\quad$ В. П. Ковальский, А. В. Бондарь // Приволжский научный вестник, 2013. - № 10(26). - С. 36-40.

8. Очеретний В. П. Проектування складів сухих будівельних сумішей з мінеральними добавками / В. П. Очеретний, В. В. Смоляк, В. П. Ковальський, А. В. Бондар // Сучасні технології, матеріали і конструкції в будівництві, 2010. - № 1. - С. 48-54.

9. Ковальський В. П. Використання глиняного порошку як мінерального мікронаповнювача у сухих будівельних сумішах / $\quad$ В. П. Ковальський, В. П. Очеретний, А. В. Бондар, А. С. Кузьмич // Международное периодическое научное издание «Научные труды SWorld». - Выпуск 2(43). Том 7. - Иваново: Научный мир, 2016. - С. 86-92.

10. Бондар А. В. Вплив мінеральних мікронаповнювачів і полімерних добавок на властивості сухих будівельних сумішей / А. В. Бондар // Інноваційні технології в будівництві. Збірник матеріалів Міжнародної науково-технічної конференції 13-15 листопада 2018 р. - Вінниця: ВНТУ, 2018. - С. 215-218.

11. Очеретний В. П. Використання поверхнево-активних речовин у якості поризуючої добавки до сухих будівельних сумішей / В. П. Очеретний, В. П. Ковальський, А. В. Бондар // Науково-технічний збірник «Сучасні технології, матеріали і конструкції в будівництві». - Вінниця: ВНТУ, 2011. - № 1 (10). - C. 33-40.

12. Очеретний В. П. Технологічні особливості введення піноутворювачів при виготовленні ніздрюватих бетонів / В. П. Очеретний, В. П. Ковальський, А. В. Бондар, А. Ф. Діденко // IV Міжнародна конференція молодих вчених GAC-2011 «Геодезія, архітектура та будівнищтво». - Львів: Національний університет "Львівська політехніка", 2011. - С. 126-129.

13. Бондар А. В. Технологічні аспекти виготовлення поризованих складів сухих будівельних сумішей / А. В. Бондар // Науково-технічний збірник «Сучасні технології, матеріали i конструкції в будівництві». - Вінниця: ВНТУ, 2013. - № 1 (14). - С. 24-27.

14. Бондар А. В. Вплив технологічних факторів на властивості поризованих будівельних розчинів на основі сухих будівельних сумішей // Сучасні технології, матеріали і конструкції в будівництві: Науково-технічний журнал. - Вінниця: ВНТУ, 2018. - № 2 (25). - С. 31-36.

15. Демьянова В. С. Моделирование состава й оптимизация процессов структурообразования смешанного вяжущего: материалы Междунар. научн.-техн. конф. / В. С. Демьянова, Н. М. Дубошина, В. Д. Черкасов и др. - Пенза, 1998. - С. 188.

16. Добрянський I. М. Вплив мікроструктури цементного каменю на його фізико-механічні властивості / І. М. Добрянський, І. І. Ніонець // Будівництво України, 2009. - №3. - С. 35-36.

17. Технология бетона, строительных изделий и конструкций / [Баженов Ю. М., Алимов Л. А., Воронин В. В. и др.]. - М.: Изд-во АСВ, 2004. - 256 с. - ISBN 5-93093-173-9.

18. Сивков С. П. Особенности процессов гидратации цементов в сухих строительных смесях / С. П. Сивков // Строительные материалы, 2008. - №2 - С. 4-5. 
19. Сивков С. П. Влияние редисперсионных полимерных порошков на свойства самониверирующихся композиций / С. П. Сивков, С. А. Голунов, Е. А. Косинов, В. Е. Зайцев // Строительные материалы, 2006. - №10. - С. 58-61.

20. Ратинов В. Б. Добавки в бетон / В. Б. Ратинов, Т. И. Розенберг. - М.: Стройиздат, 1989. - 188 с.

21. Баженов Ю. М. Технология бетона / Ю. М. Баженов. - М.: АСВ, 2002. - 500 с.

22. Моргун В. Н. Теоретическое обоснование закономерностей конструирования структуры пенобетонов / В. Н. Моргун // Труды международного конгресса «Наука и инновации в строительстве SIB-2008». Современные проблемы строительного материаловедения и технологии. Воронежский ГАСУ, 2008. - Т. 1 - С. 29-35.

23. Моргун Л. В. О взаимосвязи между термодинамическими свойствами воды и пенобетонов / Л. В. Моргун, В. Н. Моргун // Строительные материалы, 2009. - №1 . - С. 14-16.

24. Кудяков А. И. Смеси сухие растворные цементные с микрогранулированной воздухововлекающей добавкой / А. И. Кудяков, А. М. Даминова // Строительные материалы, 2010. - №1 - С. 52-53.

25. Кругляков П. М. Пены и пенные пленки / П. М. Кругляков, Д. Р. Ексерова. - М.: Химия, 1990. $432 \mathrm{c}$. 